Jurnal Ilmu Komunikasi UHO : Jurnal Penelitian Kajian Ilmu Komunikasi dan Informasi.

Volume 7, No. 1, Januari 2022, hlm 107-116

\title{
PERSUASI FITUR INSTAGRAM : STAY ON SCREEN
}

\author{
Fera Tri Susilawaty ${ }^{1)}$, Sartika Sari Wardanhi' ${ }^{2)}$, Faturachman Alputra Sudirman ${ }^{3)}$, \\ La Ode Herman Halika ${ }^{4)}$ \\ ${ }^{1,3,4}$ FISIP, Universitas Halu Oleo, Kendari \\ email: feralawata@uho.ac.id ${ }^{1}$ \\ $\underline{\text { fatur@uho.ac.id }}^{3}$ \\ $\underline{\text { Herman_halika@uho.ac.id }}^{4}$ \\ ${ }^{2}$ FISIP, Universitas Hasanuddin, Makassar \\ email: sartikasariwardanhi@unhas.ac.id
}

\begin{abstract}
ABSTRAK
Instagram tak henti berinovasi dengan mengeluarkan fitur-fitur baru yang membuat media sosial ini semakin digemari. Kepopuleran instagram membuat penulis penasaran sehingga, penulis menjadikan bahan riset untuk mengkaji keberadaan fitur-fitur instagram yang memiliki daya tarik untuk mempersuasi pengguna sehingga pengguna selalu berada pada laman instagram atau penulis ungkapkan dengan kalimat stay on screen. Riset ini juga ingin melihat fitur apa saja yang paling memiliki daya pikat dan alasan mengapa fitur tersebut memberikan pengaruh persuasi. Metode riset menggunakan deskriptif kuantitatif dengan jumlah sampel 288 orang. Beberapa data juga diambil melalui interview untuk memperoleh data kualitatif sebagai perbandingan untuk menyempurnakan hasil dari data analisis. Riset ini menunjukkan bahwa sebanyak 131 orang memilih IG story (instastory) sebagai fitur yang paling memberikan persuasi kepada mereka. 36 orang memilih IG TV, 39 orang memilih Feed, 35 orang memilih reels, 16 orang memilih direct massage (DM) dan 10 orang memilih fitur-fitur lainnya.
\end{abstract}

Kata kunci : Persuasi; Instagram; fitur; screen 
Jurnal Ilmu Komunikasi UHO : Jurnal Penelitian Kajian Ilmu Komunikasi dan Informasi.

Volume 7, No. 1, Januari 2022, hlm 107-116

\title{
INSTAGRAM FEATURE'S PERSUASSION : STAY ON SCREEN
}

\begin{abstract}
Instagram continues to innovate by releasing new features that make Instagram even more popular. The popularity of Instagram makes the author even more curious about this social media. So, the author makes research material to examine the existence of Instagram features that have an appeal to persuade users so that users are always on the Instagram page or the author expresses it with the sentence stay on screen. This research also wants to see which features have the most appeal and the reasons why these features have a persuasive effect. The research method uses descriptive quantitative with a sample of 288 people. Also took some data through interviews to obtain qualitative data as a comparison to improve the results of the data analysis. This research shows that as many as 131 people choose IG stories (instastory) as the feature that most persuades them. Thirty-six people chose IG TV, 39 people chose Feed, 35 chose reels, 16 chose direct message (DM), and ten chose other features.
\end{abstract}

Keywords: Persuasion; instagram; feature ;screen 
Jurnal Ilmu Komunikasi UHO : Jurnal Penelitian Kajian Ilmu Komunikasi dan Informasi.

Volume 7, No. 1, Januari 2022, hlm 107-116

\section{PENDAHULUAN}

Hampir semua smartphone pada berbagai merek, telah memiliki aplikasi instagram sebagai aplikasi bawaan. Pembeli tidak perlu lagi mengunduh sendiri pada Appstore atau diPlaystore. Hal ini, karena instagram dianggap sebagai salah satu aplikasi populer yang disinyalir bahwa setiap pemilik smartphone pasti memiliki akun instagram. Dari data yang dikeluarkan oleh hootsuite.com mencatat pengguna Instagram untuk Indonesia berjumlah 63 juta. Instagram pun digandrungi dari berbagai macam kalangan baik kalangan tua dan muda, kalangan profesional, kalangan komunitas, korporasi, traveller, bahkan beberapa kepala negara pun memiliki akun Instagram.

Awal kemunculan instagram pada Oktober 2010 silam, hanya berupa jejaring sosial yang berfokus pada berbagi foto, pengguna Instagram dapat mengunggah foto dan mengedit dengan berbagai tawaran filter. Instagram dapat diartikan sebagai aplikasi yang digunakan untuk mengambil foto, mengedit dengan memberikan efek foto dan membagikan kepada banyak orang sedangkan dari asal katanya instagram adalah sebuah aplikasi media jejaring sosial yang dapat menghasilkan dan mempublikasikan foto secara instan. (Syahreza \& Tanjung, 2018). Namun, kini instagram tidak lagi hanya aplikasi berbasis foto, pengguna Instagram dapat pula mengunggah video. Disamping itu, instagram mengembangkan inovasi baru dengan menambah berbagai fitur diantaranya adalah IG TV, IG live, IG story', repost, sticker, tema story' dan yang terbaru adalah reels yakni fitur yang menyerupai aplikasi tik tok.

Berkat kehadiran fitur instagram pengguna dapat memanfaatkan dengan berbagai tujuan sehingga aplikasi ini semakin digemari. Fitur canggih dapat digunakan pengguna untuk mengekspresikan diri, kemudahan berkomunikasi, berinteraksi, sarana penyampaian pesan, sarana berbagi karya visual dan media untuk membangun personal branding (Efrida \& Diniati, 2020). Fitur instagram tidak hanya dibuat canggih tetapi juga dibuat menarik dan menyenangkan agar dapat menjadi daya tarik untuk menaikkan jumlah pengguna instagram dan dapat pula menjadi bujuk rayu bagi para pengguna agar betah pada laman instagram. Hal ini didasarkan pada karakteristik jejaring sosial yang memberikan rileksasi dan hiburan sehingga pengguna aktif dapat menikmati bermain Instagram. Ketika sesorang menikmati dan merasakan banyak kebahagian dalam menggunakan sosial media, orang tersebut akan semakin aktif untuk terlibat didalamnya. (Ali-Hassan et al., 2015)

Nikmatnya bermain instagram mampu membuat pengguna ketergantungan. Riset menunjukkan adanya perilaku adiksi yang terjadi pada remaja dalam menggunakan Instagram yaitu dalam aktivitas mengeksplor berbagai foto/video dan melihat postingan IG story teman. 
Jurnal Ilmu Komunikasi UHO : Jurnal Penelitian Kajian Ilmu Komunikasi dan Informasi.

Volume 7, No. 1, Januari 2022, hlm 107-116

(Mulyani et al., 2019). Riset lainnya, ditemukan bahwa perilaku adiksi pada instagram untuk membangun relasi sosial, kebutuhan untuk mendapatkan kesenangan dan suka cita (Rahardjo et al., 2020). Ketergantungan pada Instagram tak lepas dari keberadaan fitur-fitur instagram, maka penulis tertarik untuk melakukan riset terkait fitur manakah yang mampu persuasi pengguna untuk aktif bermain instagram dan penulis juga ingin mengetahui mengapa fitur tersebut membuat pengguna betah berada pada laman instagram.

Beberapa riset terkait persuasi dan media, Fatma Laili Khoirun Nida (2014) meneliti persuasi dalam media komunikasi massa, riset ini melihat dominasi persuasi yang mengakibatkan banyaknya perubahan dalam kehidupan masyarakat akibat efek dari kehadiran komunikasi massa. Afriniar Pramitasari (2018), Model Pembelajaran Wacana Persuasif Menggunakan Situs Jejaring Instagram. Putri et al., (2015), Teknik-teknik persuasi dalam media sosial. Sari, et al., (2021), Penggunaan Bahasa persuasi pada Komentar Warganet dalam Pencegahan Wabah Covid-19 di Media Sosial Instagram. Berbeda dari riset sebelumnya, riset kali ini membahas terkait fitur mana yang memberikan persuasi yang tinggi pada pengguna serta memberikan gambaran analisis mengapa fitur tersebut memilki daya tarik untuk mempersuasi pengguna agar tetap stay on screen pada laman instagram.

\section{METODE PENELITIAN}

Riset ini menggunakan metode deskriptif kuantitatif dengan menyebarkan kuesioner pertanyaan pada sejumlah mahasiswa Ilmu Komunikasi Fisip Universitas Halu Oleo. Jumlah populasi mahasiswa Ilmu Komunikasi sebanyak 1026 orang. Penarikan sampel menggunakan metode slovin sehingga jumlah sampel yaitu 288 orang dengan margin eror 5\%. Berikut jumlah sampel berdasarkan angkatan, disajikan dalam gambar di bawah ini :

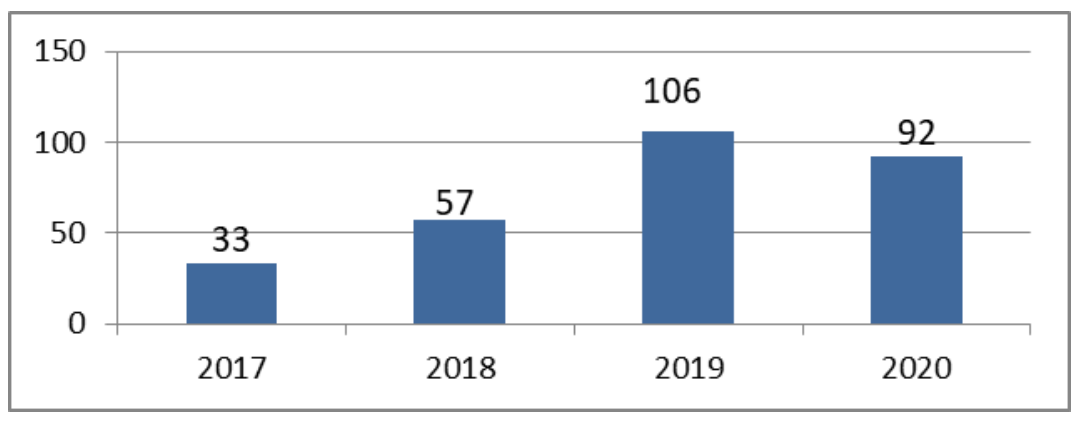

Gambar 1 Sample overview 
Jurnal Ilmu Komunikasi UHO : Jurnal Penelitian Kajian Ilmu Komunikasi dan Informasi.

Volume 7, No. 1, Januari 2022, hlm 107-116

Teknik analisis data dalam penelitian ini menggunakan statistik deskriptif dengan menggunakan tabel distribusi frekuensi. Analisis statistik deskriptif dapat digunakan bila peneliti hanya ingin mendeskripsikan data sampel dan memberikan gambaran umum setiap data yang diperoleh. Beberapa data juga diambil melalui interview untuk memperoleh data kualitatif sebagai perbandingan untuk menyempurnakan hasil dari data analisis.

\section{HASIL DAN PEMBAHASAN}

Setelah melakukan analisis data, ditemukan bahwa fitur instagram memang memilki daya tarik yang dapat mempersuasi pengguna untuk stay on screen. Dari 288 sampel, yang menyatakan fitur instagram dapat mempersuasi pengguna sebanyak 267 orang sedangkan 21 orang lainnya menyatakan tidak. Berikut hasil analisis data yang disajikan pada gambar di bawah ini :

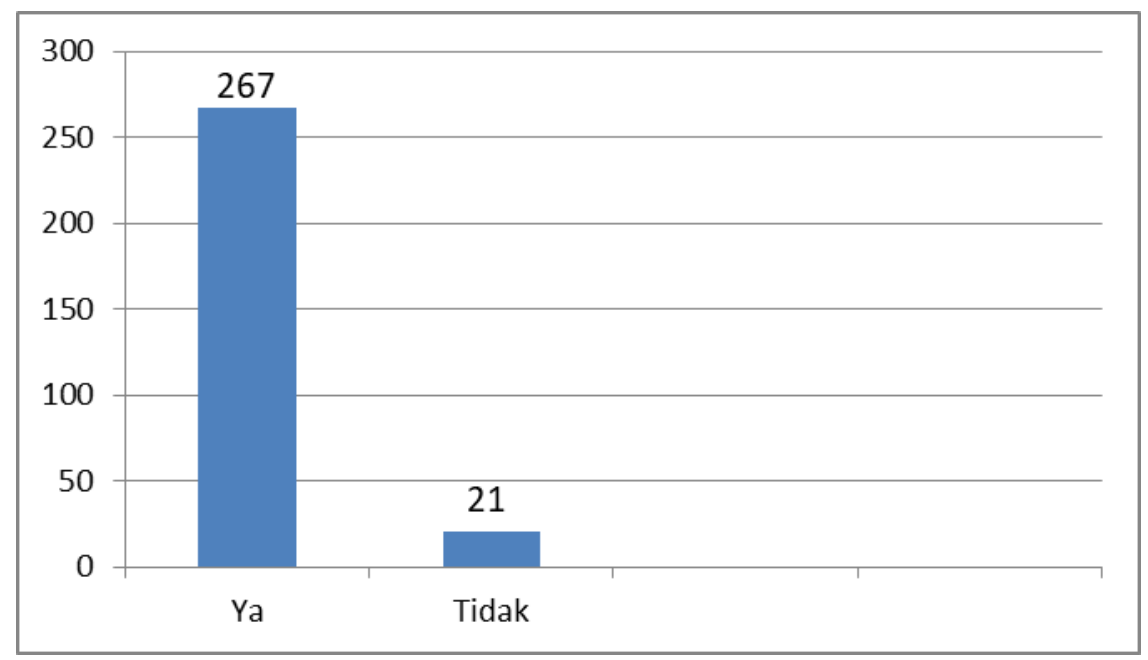

Gambar 2 Persuasi fitur Instagram pada responden

Pengguna instagram merasa betah untuk berlama-lama melihat layar smartphone, sambil memainkan jemari atas fitur-fitur instagram dari membuat dan mengunggah konten atau memantau konten pengguna instagram lainnya. Jejaring sosial instagram memungkinkan pengguna merepresentasikan dirinya, melakukan interaksi, berkomunikasi, kerja sama, berbagi dengan pengguna lainnya sehingga terbentuk suatu jalinan ikatan sosial secara virtual. (Nasrullah, 2013)

Media sosial seperti instagram memang dibuat untuk memberikan hiburan dengan menciptakan fitur-fitur yang menarik sehingga pengguna merasa senang dan ada kenikmatan yang didapatkan saat bermain instagram. Bentuk karakteristik penggunaan media sosial bagi pengguna adalah merasa terhibur, menyenangkan dan dapat memberikan rileksasi (Sanz-Blas et al., 2013) 
Jurnal Ilmu Komunikasi UHO : Jurnal Penelitian Kajian Ilmu Komunikasi dan Informasi.

Volume 7, No. 1, Januari 2022, hlm 107-116

Pada dasarnya, Instagram fokus pada aspek visual yaitu foto dan video yang berbeda dengan media sosial lainnya yang fokus pada kicauan. Fitur-fitur yang diciptakan mendukung untuk membuat konten/postingan yang menarik seperti menambahkan filter editan pada gambar, tema, sticker dan gimmick-gimick yang seru.

Adapun hasil riset terkait, fitur manakah yang paling memberikan dampak persuasi sehingga pengguna stay on screen, ditemukan lima fitur yang paling banyak digemari. Berikut disajikan dalam gambar di bawah ini.

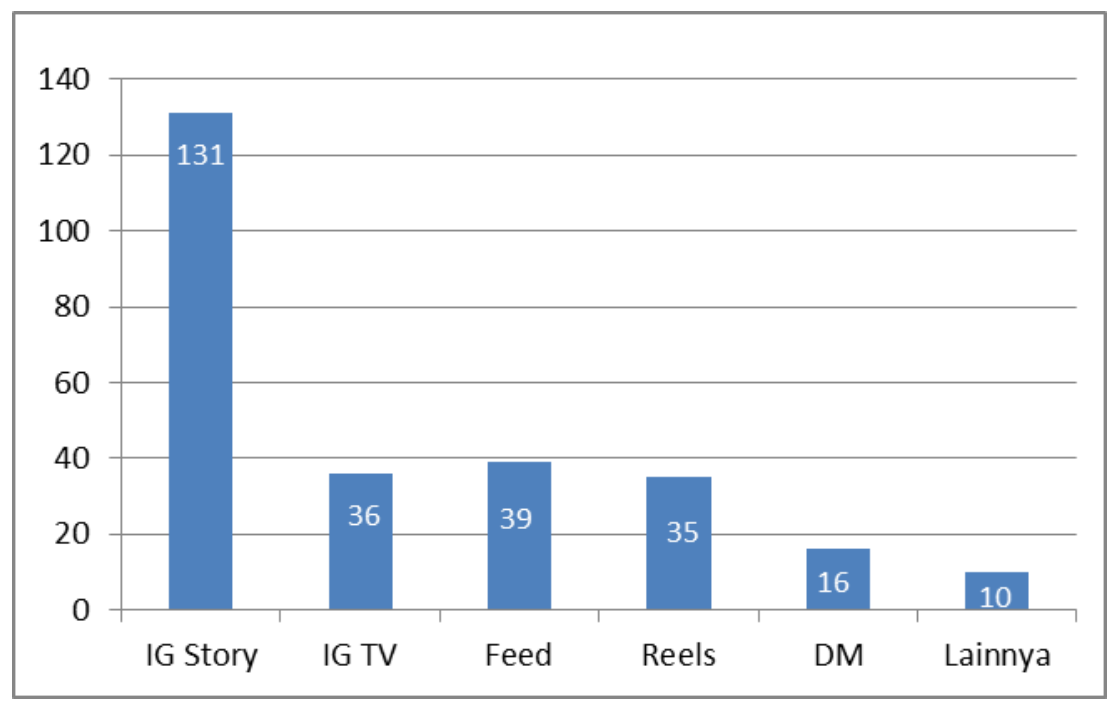

Gambar 2 : Fitur Instagram pilihan responden

Ada 288 sampel yang berpartisipasi dalam riset ini, ditemukan bahwa sebanyak 131 orang memilih IG story (instastory) sebagai fitur yang paling memberikan persuasi kepada mereka. 36 orang memilih IG TV, 39 orang memilih Feed, 35 orang memilih reels, 16 orang memilih direct massage (DM) dan 10 orang memilih fitur-fitur lainnya. Pemilihan fitur ini, cukup relevan bila dikaitkan dengan teori uses and gratification, tujuan teori ini untuk mengetahui alasan individu menggunakan media massa, memanfaatkan media massa, dan hal-hal apa saja yang mereka gemari dari berbagai pilihan media massa. (Severin \& Tankard, 2011). Pengguna Instagram dalam riset ini adalah mahasiswa Ilmu Komunikasi Fisip menjadikan IG story sebagai fitur yang paling mereka sukai.

IG story atau yang biasa disebut dengan instastory, adalah fitur yang merekam video pendek berdurasi 15 detik. Pada fitur ini, pengguna juga dapat melakukan foto dengan berbagai macam filter wajah, menghadirkan video boomerang, thema, jenis tulisan, superzoom, video mundur, handsfree, sticker, emoticon, berbagi lokasi, games, melakukan 
Jurnal Ilmu Komunikasi UHO : Jurnal Penelitian Kajian Ilmu Komunikasi dan Informasi.

Volume 7, No. 1, Januari 2022, hlm 107-116

survey kecil-kecilan dan yang terbaru adalah berbagi musik. Secara umum, dapat disimpulkan responden memilih IG story karena menarik ditonton. Menghadirkan video pendek sehingga tidak bosan untuk ditonton. Mereka dapat menonton berbagai video-video yang menarik dari banyak pengguna lainnya.

Terkait dalam membuat postingan/konten, responden menggunakan fitur IG story dengan memanfaatkan fitur-fitur tambahan dalam fitur IG story. Postingan mereka dapat terlihat lebih indah, lucu dan menarik dengan tambahan fitur tersebut, sehingga para followers mereka dapat melihat postingan yang dihasilkan, tak jarang postingan mereka ditanggapi atau direpost balik oleh followersnya. Hal ini sejalan dengan teori Mc Clelland yang menjelaskan ada tiga bentuk kebutuhan yaitu prestasi, kekuasaan dan afiliasi. Prestasi yaitu kondisi dimana dapat menonjolkan keunggulan seperti melakukan sesuatu yang dapat memberikan umpan balik atas apa yang dilakukan sehingga mengetahui ada progress yang didapatkan atau tidak. Power yaitu kebutuhan atas keinginan untuk mempengaruhi orang lain dan afiliasi adalah kebutuhan untuk berinteraksi dengan orang lain. (Siagian, 2018).

Hal menarik adalah banyak responden menyukai IG story karena menemukan hal-hal random namun mereka menyukainya. Random yang dimaksud disini adalah hal remeh temeh yang ada pada postingan pengguna lainnya. Postingan tersebut dapat berupa masalah kehidupan sehari-hari, lelucon, kegalauan dan kekesalan. Postingan random akan semakin dianggap penting ditonton apabila postingan berasal dari orang yang disukai seperti keluarga, pacar, teman, artis, selebgram, olahragawan, idola, akun lelucon, akun gosip dan sebagainya.

Dalam IG story, pengguna dapat pula mengetahui siapa yang melihat postingan mereka. Hal ini menjadi faktor bahwa menggunakan fitur IG dapat menjadikan mereka eksis. Mereka mengecek berapa orang yang melihat postingan mereka dan siapa-siapa saja yang melihat. Semakin banyak dilihat semakin mereka senang. Selain itu, bila yang melihat adalah orang yang disukai mereka pun merasa bahagia. Dilihat banyak orang akan menimbulkan pengakuan diri dan adanya sesuatu yang ingin dicapai yaitu banyak orang yang melihat instastory. (Hidayah \& Nuqul, 2019). Maka tak heran, mereka begitu aktif dalam bermain Instagram dan stay on screen dengan terus mengecek siapa saja yang melihat postingan mereka.

Feed merupakan fitur untuk mengunggah foto. Pengguna dapat mengedit, memberikan komen dan likes pada foto tersebut. Pada riset ini, feed menempati urutan kedua dengan jumlah 39 responden. Kebiasaan pengguna dalam scrolling postingan feed membuat pengguna untuk selalu stay on screen. Survei yang dilakukan oleh Anca Jurj (2019) 
Jurnal Ilmu Komunikasi UHO : Jurnal Penelitian Kajian Ilmu Komunikasi dan Informasi.

Volume 7, No. 1, Januari 2022, hlm 107-116

menunjukkan bahwa dari 82 partisipan, $61 \%$ menghabiskan waktu 3-5 jam untuk scrolling pada instagram. Disamping itu, banyaknya akun buzzer yang mengunggah berbagai informasi dan hal-hal yang viral menjadi alasan feed digemari oleh responden.

Berbeda dari fitur IG story, feed tidak memberikan informasi siapa saja yang dapat melihat postingan mereka sehingga pengguna dapat memantau (stalking) pengguna lainnya. Mereka dapat stalking teman, artis, pacar, orang yang ditaksir dan mantan pacar tanpa diketahui. Instagram memberikan layanan informasi sesuai kebutuhan pengguna, baik mencari berita, informasi public figure, informasi produk barang dan jasa, informasi seseorang yang disukai ataupun informasi teman sendiri (stalking). (Irwanto \& Hariatiningsih, 2019). Adapun likes dan komen menjadi alasan pengguna untuk mengunggah foto dan ajang show off untuk memamerkan keindahan dan kreativitas foto yang ditampilkan. Disamping itu likes dan komen memberikan peluang pada pengguna untuk tetap stay on screen, waktu ini digunakan untuk kembali melakukan pengecekan mengenai unggahan atau postingan sebelumnya, untuk melihat siapa yang memberikan likes dan komen (Irwanto \& Hariatiningsih, 2019)

Ajang show off dalam fitur feed digemari oleh pengguna, tidak hanya untuk posting foto show off terkait gaya hidup. Namun, pengguna juga menikmati foto-foto show off dari pengguna lainnya berseliweran pada timeline mereka. Dengan kata lain, pada fitur feed pengguna dapat memproduksi konten dan dapat mengkonsumsi konten show off . Seperti yang dikatakan oleh Du Gay dalam (Junaedi et al., n.d.) bahwa internet dapat membuat budaya baru dimana konsumen dapat memproduksi dan mengkonsumsi konten secara bersamaan yang berkaitan dan melingkupi satu sama lainnya.

Fitur ketiga dengan jumlah 36 responden memilih, IG TV yang merupakan fitur dimana pengguna dapat membuat dan menonton video dengan durasi yang lebih lama. Hampir seperti youtube, IG TV memberikan kenyaman responden dalam menonton video berdurasi panjang tanpa adanya gangguan iklan. Semakin lama video yang mereka tonton tentu saja semakin lama mereka berada pada screen instagram.

Kepopuleran aplikasi tik tok, membuat instagram meluncurkan fitur reels. Reels menempati urutan ke empat dengan jumlah 35 responden. Reels adalah fitur yang mirip dengan aplikasi tik tok. Pengguna dapat membuat konten video dengan tambahan fitur-fitur lainnya seperti musik, filter, dan mengatur tata letak video yang membuat konten tersebut lebih menarik. Disamping itu, pengguna instagram dapat menonton reels pengguna lainnya yang sedang trending. Adapun fitur direct massage (DM) berada di urutan ke lima dengan 
Jurnal Ilmu Komunikasi UHO : Jurnal Penelitian Kajian Ilmu Komunikasi dan Informasi.

Volume 7, No. 1, Januari 2022, hlm 107-116

jumlah 16 responden. Alasan responden memilih DM karena pengguna dapat mengobrol dan menyapa pengguna lainnya secara personal. Disamping itu, pada DM Instagram memungkinkan para pengguna menyapa idola serta selebriti yang mereka suka secara pribadi. Instagram menawarkan banyak fitur-fitur menarik yang dapat membuat pengguna untuk tetap stay on screen. Jin Yea Jang, dkk (2015) menyebutkan alasan instagram digemari karena sifat fitur efek instant yang dapat merubah foto menjadi lebih artistik. Beberapa fitur baru menyerupai aplikasi sosial media lainnya seperti IG TV yang menyerupai youtube dan fitur reels yang mirip aplikasi tik tok. Hal ini menunjukkan instagram dapat menjadi sosial media terpadu (one stop social media) sehingga pengguna dapat menggunakan satu sosial media yakni instagram dengan dapat merasakan experience bermain sosial media lainnya seperti youtube dan tik tok.

\section{KESIMPULAN}

Riset ini menunjukkan bahwa fitur Instagram dapat memberikan persuasi kepada pengguna agar stay on screen, Dari 288 sampel, 267 menyatakan bahwa fitur Instagram mampu memberikan daya tarik persuasi, sedangkan 21 lainnya menyatakan tidak. Terdapat lima fitur yang dianggap mampu memberikan persuasi yaitu IG story, feed, IG TV, reels dan DM. IG story mendapatkan posisi pertama yang dipilih responden, dengan jumlah 131 orang. Alasannya adalah, IG story hanya berdurasi pendek dan memiliki fitur-fitur tambahan yang dapat membuat postingan yang menarik dan dapat menonton banyak postingan pengguna lainnya yang unik dan tidak bosan menonton karena hanya berdurasi 15 detik. Postingan random pengguna memberikan kenikmatan tersendiri dalam bermain Instagram dan pengguna dapat mengetahui siapa yang melihat postingan mereka sehingga pengguna merasa eksis dan ada pengakuan diri. Banyaknya fitur instagram, memungkinkan instagram sebagai one stop social media yakni pengguna dapat menggunakan hanya satu sosial media instagram namun dapat merasakan experience bermain sosial media lainnya. 
Jurnal Ilmu Komunikasi UHO : Jurnal Penelitian Kajian Ilmu Komunikasi dan Informasi.

Volume 7, No. 1, Januari 2022, hlm 107-116

\section{DAFTAR PUSTAKA}

Ali-Hassan, H., Nevo, D., \& Wade, M. (2015). Linking dimensions of social media use to job performance: The role of social capital. The Journal of Strategic Information Systems, 24(2), 65-89.

Efrida, S., \& Diniati, A. (2020). Pemanfaatan fitur media sosial Instagram dalam membangun personal branding Miss International 2017. Jurnal Kajian Komunikasi, 8(1), 57-71.

Hidayah, S. Y. W., \& Nuqul, F. L. (2019). Bijak dalam Bersosial Media: Pengaruh Pemenuhan Kebutuhan Psikologis Terhadap Perspective Taking Dalam Mengunggah Instastory. Psikoislamedia: Jurnal Psikologi, 3(1).

Irwanto, I., \& Hariatiningsih, L. R. (2019). Identitas Diri pada Media Sosial (Konstruksi Sosial dan Potensi Rumor Pengguna Instagram). Jurnal Komunikasi, 10(2), 184-190.

Jang, J. Y., Han, K., Shih, P. C., \& Lee, D. (2015). Generation like: Comparative characteristics in instagram. Proceedings of the 33rd Annual ACM Conference on Human Factors in Computing Systems, 4039-4042.

Junaedi, F., Sukmono, F. G., Sugiana, D., Setiaman, A., Sari, D. K., Wibowo, N. A., Herwandito, S., Sjuchro, D. W., Yusanto, Y., \& Ramadhani, E. (n.d.). Komunikasi.

Jurj, A. (2019). Insta-story for personal branding and product promotion. MASTERCOM-Politehnica Graduate Student Journal of Communication, 4(1).

Mulyani, I., Mikarsa, H. L., \& Puspitawati, I. (2019). Perilaku Adiksi pada Instagram di Kalangan Remaja Instagram Addiction Behavior among Adolescents.

Nasrullah, R. (2013). Cyber Media. Yogyakarta: IDEA Press Yogyakarta.

Nida, F. L. K. (2014). Persuasi dalam media komunikasi massa. Jurnal Komunikasi Penyiaran Islam “AT-TABSYIR, 2(2), 77-95.

Pramitasari, A. (2018). MODEL PEMBELAJARAN MENULIS WACANA PERSUASIF DENGAN MEDIA SITUS JEJARING SOSIAL INSTAGRAM PADA MAHASISWA UNIVERSITAS PEKALONGAN. Pertemuan Ilmiah Bahasa Dan Sastra Indonesia (PIBSI).

Putri, F. I., Lukmantoro, T., \& Gono, J. N. S. (2015). Teknik-teknik Persuasif Dalam Media Sosial (Studi Analisis Isi Kualitatif Pada Akun Mentor Parenting Ayah Edy di YouTube). Interaksi Online, 4(1).

Rahardjo, W., Qomariyah, N., Andriani, I., Hermita, M., \& Zanah, F. N. (2020). Adiksi Media Sosial pada Remaja Pengguna Instagram dan WhatsApp: Memahami Peran Need Fulfillment dan Social Media Engagement. Jurnal Psikologi Sosial, 18(1), 5-16.

Sanz-Blas, S., Ruiz-Mafé, C., Marti-Parreño, J., \& Hernández-Fernández, A. (2013). Assessing the influence of motivations and attitude on mobile social networking use. Global Business Perspectives, 1(2), 164-179.

Sari, O. P. (2021). Penggunaan Bahasa Persuasi pada Komentar Warganet dalam Pencegahan Wabah Covid-19 di Media Sosial Instagram. LOCANA, 4(1), 99-108.

Severin, W. J., \& Tankard, J. W. (2011). Teori komunikasi: sejarah, metode dan terapan didalam media massa. Kencana.

Siagian, S. P. (2018). Teori motivasi dan aplikasinya. Rineka Cipta 